\title{
The Covid-19 Pandemic and Its Relation to the Commercial (Economic) Law, Labor Law, State and International Role
}

\author{
Nomensen Freddy Siahaan ${ }^{1 *}$
}

\author{
${ }^{1}$ University of Mulawarman Samarinda \\ *Corresponding email: nomensen.freddy1989@gmail.com
}

\begin{abstract}
The Covid-19 pandemic is an epidemic global. This affects many things such as health, economy, social, culture, law, including Manpower, and other sectors. Of course, this is not what we want and beyond our expectations. Now all eyes of people in the world are very concerned about the spread of this virus because if we consider this virus to be underestimated, then we or people around us might become victims. At this time, the author will focus on research on manpower which is also affected by the Covid-19 Pandemic. This is the reason and concern for the author because it has shaken the labor sector, especially for workers affected by this Termination of Manpower. The role of the State and the International Labor Organization is urgently needed because this emergency was massive and brought many disadvantages to a lot of parties, especially workers who were laid off. In domestic situations, the Government must actively provide a social safety net for people affected by the termination of Manpower. Not only within the country, international institutions such as the ILO should also provide assistance and technical input in several areas, from training and skills to microfinance and small business development, and others.
\end{abstract}

Keywords: Force majeure, Economic recession, Manpower

\section{INTRODUCTION}

As we all know, the Covid-19 pandemic is an epidemic in global. This affects many things from different sectors such as health, economy, social, culture, law, including Manpower, and others. Of course this is not what we want and beyond our expectations. Now all eyes of people in the world are very concerned about the spread of this virus because if we consider this virus to be underestimated, then we or people around us might become victims.

At this time, the author will focus on research on Manpower which is also affected by the Covid-19 Pandemic. As the news quoted by the author from this site is very influential from an Manpower perspective. Deputy Chairperson of the Indonesian Chamber of Commerce and Industry (Kadin) in the field of MSMEs, Suryani Motik said that residents who were victims of termination of Manpower due to the corona pandemic (Covid-19) could reach 15 million people. This figure is greater than the amount released by the Ministry of Manpower (Kemenaker) of 2.8 million as of April 20. Because, said Suryani, the number had not been added to the micro, small and medium enterprises (UMKM) which were also affected.

So if there were 2 million, the facts could be 15 million. That is possible 2 million reported. Did UMKM report, right? said Suryani in an online discussion via the
Zoom application. In fact, Suryani estimates that the number is much higher, between 30- 40 million people who are victims of layoffs due to this pandemic. Because, she said, many residents were also forced to not be able to go home because it was prohibited. Not to mention that it was said that those who did not return home. Maybe 20 million in Jakarta. Maybe there are nearly 30 million workers, 40 million who are unemployed which was told by Suryani.

Not to mention that globally, layoffs also occurred on a large scale. The mass layoffs resulting from the corona virus crisis could exceed 25 million people worldwide, a figure estimated just days ago. United States officials say that US unemployment has spiked to highs in a clear sign of economic disaster.

The International Labor Organization (ILO) reports as much as 81 percent of the global workforce of around 3.3 billion, or 2.67 billion workers currently affected by workplace closures due to the corona virus (Covid-19) pandemic. Meanwhile 1.25 billion workers among them are threatened with termination of Manpower.

As an example occurred one of the world class companies on the LinkedIn Workforce. These layoffs affect approximately 6 percent of LinkedIn employees worldwide, including in the UK. In his message to employees, LinkedIn CEO Ryan Roslansky said, this layoff is the only wave of layoffs planned by LinkedIn. 
This announcement is made public as many business sectors cut the number of employees around the world. Whether it's from the retail business to the airline business. This is the reason and concern for the author because it has shaken the labor sector, especially for workers affected by this Termination of Manpower.

\section{METHODS}

This paper is a Normative Legal Research. Normative Legal Research is a scientific procedure to find the truth based on the logic of the normative legal scientific. The scientific logic of normative Legal Research is developed by the scientific concentrate and ways of thinking of normative jurisprudence and their objects are regulation themselves.

“Referring to Soerjono Soekanto's statement which states that [1] The legal materials, as objects of literature paper are divided into 3 (three) kinds of primary legal materials, secondary legal materials, tertiary legal materials. The legal materials of this paper are used:

a. Primary Legal Materials which the characteristic is bound by the writing, i.e.:

1) Constitution of Republic of Indonesia Year 1945;

2) Civil Code;

3) Act Number 13 of 2003 regarding to Manpower;

b. Secondary Legal Materials are the materials which explain about the primary legal materials such as books, journals, papers, newspapers, and report of legal research, and all varieties of written material on the internet website regarding to termination of employees and the relationship toward legal science.

\section{RESULTS AND DISCUSSION}

\subsection{Termination of Manpower on a large scale while the covid-19 outbreak struck in terms of Civil Theory (Commercial Law)}

The tasks of our government to handle welfare issues have not been completed yet. Since the establishment of Republic of Indonesia on 1945, the performance of the government towards protection of Indonesian Manpower has never reached a satisfactory level yet.

According to Act Number 13 of 2003 concerning Manpower, Article 1 states that Manpower is anyone who is able to carry out work both within and outside of a work relationship in order to produce goods and services to meet the needs of society.

According to Act Number 13 of 2003 concerning Manpower, Article 8 concerning manpower planning and manpower information includes: Job opportunities, job training.

So if there is a massive layoff due to the covid-19 pandemic, the goal cannot be achieved as stated in Act Number 13 Year 2003 concerning Manpower Article 4 alphabet (a) to empower and improve labor efficiency optimally and humanely because of the workers who affected by Termination of Manpower Relations will definitely be very disadvantaged. Their income was suddenly cut off and they could not meet their daily needs as usual. Surely they will find it very difficult to find new jobs in the midst of this corona virus outbreak.

If it happens, then the goal in Article 4 alphabet (d) cannot be achieved because if there is no income due to this termination of Manpower, they will not be able to improve their own life and even their families. Never mind to live in prosperity, to fulfill their daily needs they have to think seriously because they are no longer workers who get monthly income as usual. But Author must also consider from another perspective why the Company or Entrepreneur is doing layoffs on a large scale.

Firing carries a stigma in many cultures, and may hinder the jobseeker's chances of finding new Manpower, particularly if they have been terminated from a previous job. Jobseekers sometimes do not mention jobs from which they were fired on their resumes; accordingly, unexplained gaps in Manpower, and refusal or failure to contact previous employers are often regarded as "red flags". [2]

Manulang [3] argues that the term Termination of Manpower can provide several meanings, such as Retrenchment, Termination of Manpower associated with economic issues, such as economic recession, marketing problems, so that companies are unable to provide income to employees.

If Author look at the several types of Termination of Manpower above, then Termination of Manpower due to the corona virus outbreak is included in the category of Retrenchment due to a massive economic recession around the world. The business of the Entrepreneur or the Company cannot run well because everyone is worried about their own safety and health.

Flippo [4] distinguishing termination of Manpower outside the context of retirement into 3 categories, such as Layoff, this decision will become a reality when a qualified employee must be retired because the company no longer needs his service contribution, Outplacement, is an activity termination of Manpower because the company wants to reduce a lot of workers, Discharge, based on the fact that employees lack satisfactory work attitudes and behavior.

If it is related to this case, the Termination of Manpower that occurs is included in the Outplacement category because the Company wants to make efficiency with its unhealthy finances because the business is not running smoothly due to the corona outbreak, so to overcome this the company reduces a lot of manpower. Force majeure is a common clause in contracts that essentially frees both parties from liability or obligation when an extraordinary event or circumstance beyond the control of the parties, such as a war, strike, riot, crime, epidemic or an event described by the legal term act of God, prevents one or both parties from fulfilling their obligations under the contract. In practice, most force 
majeure clauses do not excuse a party's non-performance entirely, but only suspend it for the duration of the force majeure. [5]

When force majeure has not been provided for in the contract (or the relevant event does not fall within the scope of the force majeure clause), and a supervening event prevents performance, it will be a breach of contract. The law of frustration will be the sole remaining course available to the party in default to end the contract. If the failure to perform the contract deprives the innocent party of substantially the whole benefit of the contract it will be a repudiatory breach, entitling the innocent party to terminate the contract and claim damages for that repudiatory breach. [6]

Force majeure or what is often translated as "forceful situation" is a condition in which a debtor is prevented from carrying out his performance due to circumstances or events that are unexpected at the time the contract was made, these circumstances or events cannot be accounted for to the debtor, while the debtor is not in a state of bad faith. See article 1244 of the Civil Code.

"In this case, the events which constitute force majeure have never been predicted by the previous parties about the occurrence of such events, so it should have been negotiated between the parties."

In other words, that the event which was a force majeure was not included in the basic assumption of the parties when the contract was made. Basically, article 1244 and article 1245 of the Civil Code only regulate the issue of force majeure in relation to the compensation for loss and interest costs, however the formulation of these articles can be used as a guide in defining force majeure in general.

From the formulations in the articles of the Civil Code as mentioned above, it can be seen that the causes of force majeure according to the Civil Code are as follows Force majeure for unforeseen reasons, Force majeure because of the force, Force majeure because each of these acts is prohibited.

If it is associated with a massive layoff of Manpower with the coronavirus outbreak that is currently sweeping globally, according to the author, this is included in the Force Majeure category for unexpected reasons because it is beyond human control in general and only God can know about it. We don't know how long this corona virus will last. So like it or not, it is better for entrepreneurs or companies to close their businesses than to suffer continuous losses.

This happens because of force majeure and occurs globally. Of course everyone in the world does not want this corona virus outbreak. However, because it is happening and global epidemics, each individual is competing to save his / her own economy, including companies or entrepreneurs.

\subsection{The Roles of State and International Organization to Face Massive of Termination of Manpower that has been Engulfing the World}

The author thinks that for the first step it would be wise if the government provides incentives through the Pre- employment card with the benefit of six hundred thousand cash per month and will be given for 4 months. But this is not for long time because it will pamper the Indonesian so that its original ability is not appear because it feels like it is more than enough get subsidy from the Government.

Therefore, society needs to be educationally creative in order to continue their life in so that can be able to adapt developing of situation that happens to the world. The public should not be left behind so it continues to burden the Government because the Government itself has been quite overwhelmed in dealing with the economic recession that is engulfing this country.

In addition, it can also be taken to reduce the number of Termination of Manpower. First, the Ministry of Manpower gives the opportunity to discuss and mentor between Employers, Work Force, and Manpower to help companies, especially those engaged in the strategic sector (ensuring the sustainability of the community or the public). There will be a problem that will be faced during this covid-19 and should the Ministry of Manpower should be able to provide solutions to solve these problems.

Other solutions are offered by reducing the top rate of income so that for a while there are no incentives or bonuses for those who achieve the work target. Perhaps his award can be given in other form that is more affordable. It can also be given restrictions or even overtime is issued. So Manpower is more likely to work effectively as working hours progress so Manpower productivity will be increase.

On a world scale, the ILO expects the role of the ILO to supervise and issue policies that protect the economy of middle and lower middle class people, especially Manpower who have been affected by covid-19. The ILO's broad policies are set by the International Labour Conference, which holds annual meetings inviting its constituents. In the event of a Covid-19 outbreak, the ILO held an emergency conference to discuss the massive of Termination of Manpower that is engulfing the business sector and the corporate economy today.

According to the author's opinion, in order to solve this massive of Termination of Manpower and protect the welfare of its Workforce that has been affected by termination of Manpower, the ILO should provide technical assistance and input in a number of areas, from training and skills to microfinance and small business development. The ILO can suggest to countries for transition from a centralized economy to a market economy on Manpower policy, job market, and human resources. 


\subsection{Termination of Manpower and Its' Relation to The Economic Growth of a Country}

Economic growth is briefly interpreted as a long-term increase in per capita output. The pressure is focused on three aspects, such the process, the increase in per capita and for long term. Economic growth is a process, not a description of the economy at some point (one shoot). Here can be seen the dynamic aspect of an economy, which is seeing the economy as something that develops or changes over time. The pressure on change or development itself. [7]

This kind of trend is evident in modern economic growth theories. On the contrary, the historical sect emphasizes the theory built not only on its theoretical logical aspects but also emphasizes its empirically and simultaneously finds the meaning of economic growth, especially for the poor, the underdeveloped and society as a whole.

Due to the global and relatively high economic recession, it has an impact on declining economic growth and business entities, thus requiring business entities to streamline their spending by laying off some of their workforce so it will not suffer losses. In the author's opinion, this is very natural because the Covid-19 pandemic is a force majeure event and cannot be avoided because it occurs globally. Of course every country prioritizes the health of its citizens over the economy. This does not mean that the author puts aside economic growth. But ideally, economic growth and the health of citizens are closely related and must be able to run harmoniously because it does not mean that the economy is better but the health of citizens is worse, and vice versa.

\section{CONCLUSION}

In domestic situations, the Government must actively provide a social safety net for communities that have been affected by termination of manpower. Not only within the country, but also international institutions such as the ILO should participate in providing technical assistance and input in a number of areas, from training and skills to microfinance and small business development. The ILO can provide input for countries to make the transition from a centralized economy to a market economy on manpower policies, the manpower market and human resources.

\section{ACKNOWLEDGMENT}

The authors would like to thank the Faculty of Law, University Of Mulawarman, Samarinda, for facilitating this activity so that the authors get many benefits for scientific development.

\section{REFERENCES}

[1] S. Soekanto and S. Mamudji, Penelitian Hukum Normatif: Suatu Tinjauan Singkat. Jakarta: PT Raja Graf Persada, 2003.
[2] G. Totladze, "Managing Information Resources In An Organization. A Perspective Upon Its Mass Media Exposure," Def. Resour. Manag. 21st Century, vol. 9, no. 9, pp. 282-291, 2014.

[3] H. S. Manulang, Pokok-pokok Hukum Ketenagakerjaan di Indonesia. Jakarta: Rineka Cipta, 2008.

[4] E. B. Flippo, Personal Management, Organization, and Strategy. Mason. Thomson, 1984.

[5] A. Momenirad and M. Telba, "Pondering About Doctrine Of Frustration Of Contract On The Common Law And Comparison With The Force Majeure On The Principles Of International Commercial Contract," Law Q., vol. 46, no. 4, pp. 611-625, 2016.

[6] D. Nolan, "Hongkong Fir Shipping Co. Ltd. v. Kawasaki Kisen Kaisha Ltd., the Hongkong Fir (1961)," Ltd. v. Kawasaki Kisen Kaisha Ltd., Hongkong Fir, pp. 269-297, 1961.

[7] L. M. Putri and M. Triani, "Analisis Hubungan Korupsi, Demokrasi Dan Pertumbuhan Ekonomi Di Indonesia," J. Kaji. Ekon. dan Pembang., vol. 2, no. 4, 2020. 